\title{
Disorders $\mathrm{Ca}^{2+}$ Homeostasis in Rat Cardiac Mitochondria Affected by Adriamycin
}

\author{
AKIHIRO KAGIYAMA, GENKO SHIN, HIROSHI UETA, TAKACHIKA SHOJI, \\ SHIRO MIMORI AND RYOHEI OGURA
}

\author{
Department of Medical Biochemistry, Kurume University School of Medicine, \\ Kurume, 830 Japan
}

Received for publication June 9, 1988

\begin{abstract}
Summary: To determine the mechanism of adriamycin (ADR) induced cardiotoxicity, the effects of ADR on the $\mathrm{Ca}^{2+}$ uptake and release of cardiac mitochondria were investigated. Male Wistar rats were injected intraperitoneally with $4 \mathrm{mg} / \mathrm{kg}$ body weight of $\mathrm{ADR}$ for 6 consequtive days, and mitochondria were isolated from heart muscle. $\mathrm{Ca}^{2+}$ uptake and release of cardiac mitochondria were measured spectrophotometrically using a metallochromic dye antipyrylazo III. The total calcium content was determined by atomic absorption. ADR administration resulted in reductions of the $\mathrm{Ca}^{2+}$ uptake velocity, $\mathrm{Na}^{+}-\mathrm{Ca}^{2+}$ exchange velocity and the calcium content in cardiac mitochondria. The data reported here is useful for understanding the pharmacological effect of adriamycin to unfavourable side-effect, cardiotoxicity.
\end{abstract}

Key words: adriamycin - cardiotoxicity - mitochondria $-\mathrm{Ca}^{2+}$ - uptake $-\mathrm{Na}^{+}$$\mathrm{Ca}^{2+}$ exchange

\section{Introduction}

Adriamycin (ADR) is one of the most effective antitumor agents. However, the clinical applications of ADR have been limited because of its unfavourable side effects. There are many reports concerning the causes of its cardiotoxicity, but the precise mechanisms are still unknown (Doroshow et al. 1980). Thayer (Thayer, 1984) suggested relationship between the elevation of serum lipid peroxides and the development of ADR-induced cardiomyopathy. And recent studies show that cardiac mitochondria are responsible for formation of semiquinone free radical, active oxygen and consequent radical-initiated lipid peroxidation (Davies et al. 1983; Nohl and Jordan, 1983; Pollakis et al. 1984). We have already reported the following biochemical changes in cardiac mitochon- dria affected by ADR: elevation of lipid peroxide (Ogura, 1982; Yoon et al. 1983), decrease of CoQ10 content (Ogura, 1982), uncoupling of phosphorylation (Ogura, 1982; Yoon et al. 1983) and decline of riboflavin content (Hino et al. 1985).

In general, the intracellular distribution of $\mathrm{Ca}^{2+}$ is known to play extremely important role in the regulation of cellular viabilities. Disorders of $\mathrm{Ca}^{2+t}$ homeostasis of cardiac cells have been reported to associate with several types of cardiomyopathy (Farber, 1981; Nylen and Wrogemann, 1983; Jasmin and Proschek, 1984). Disruption of $\mathrm{Ca}^{2+}$ homeostasis of cardiac mitochondria may be one of the mechanisms of ADR-induced cardiomyopathy. In this paper, we report the effect of $\mathrm{ADR}$ on $\mathrm{Ca}^{2+}$ uptake velocity, $\mathrm{Na}^{+}-\mathrm{Ca}^{2+}$ exchange velocity and calclium content in cardiac mitochondria. 


\section{Materials and Methods}

Male Wistar rats weighing about $200 \mathrm{~g}$ were injected intraperitoneally with $4 \mathrm{mg}$ / $\mathrm{kg}$ of ADR (adriacin, Kyowa Hakko Kogyo Co. Ltd.) for 6 consecutive days (Ogura, 1982). On the 7 th day from the original injection, the animals were sacrificed by decapitation. The heart was excised quickly and placed in an ice-cold solution of $70 \mathrm{mM}$ sucrose, $220 \mathrm{mM}$ mannitol and $5 \mathrm{mM}$ morpholinopropane sulfonic acid. Mitochondria were prepared from heart muscle according to the procedure of Ogura et al. (Ogura et al. 1986). The protein concentration of the mitochondrial suspension was determined by the biuret method with bovine serum albumin as a standard (Gornall et al. 1949).

\section{1) $\mathrm{Ca}^{2+}$ uptake and $\mathrm{Na}^{+}$-induced $\mathrm{Ca}^{2+}$ release}

$\mathrm{Ca}^{2+}$ uptake and $\mathrm{Na}^{+}$-induced $\mathrm{Ca}^{2+} \mathrm{re}$ lease were measured by the method of Wolkowicz et al. (Wolkowicz et al. 1983). The reaction medium consisted of $70 \mathrm{mM}$ $\mathrm{KCl}, 0.225 \mathrm{M}$ sucrose, $9 \mathrm{mM}$ HEPES, $1.5 \mathrm{mM}$ $\mathrm{KH}_{2} \mathrm{PO}_{4}, \mathrm{pH} 7.3,80 \mu \mathrm{M}$ antipyrylazo III, $5 \mathrm{mM}$ potassium succinate, $10 \mu \mathrm{g}$ rotenone with $3 \mathrm{mg}$ protein in a final volume of $3 \mathrm{ml}$ at $24^{\circ} \mathrm{C}$. Following a $1-2 \mathrm{~min}$ incubation period at $24^{\circ} \mathrm{C}$, the $\mathrm{Ca}^{2+}$ uptake was initiated by the addition of $10 \mu \mathrm{l}$ of $4 \mathrm{mM}$ $\mathrm{CaCl}_{2}$ ( $40 \mathrm{n}$ moles). The $\mathrm{Ca}^{2+}$ uptake by mitochondria was monitored by dual wavelength spectroscopy using antipyrylazo III at the wavelength pair $720-790 \mathrm{~nm}$ by means of Hitachi 557 dual wavelength spectrophotometer. After $\mathrm{Ca}^{2+}$ uptake and prior to the $\mathrm{Na}^{+}$addition, $1 \mu \mathrm{M}$ ruthenium red was added to inhibit further $\mathrm{Ca}^{2+}$ uptake. The $\mathrm{Na}^{+}$-induced $\mathrm{Ca}^{2+}$ release was initiated by $3 \mathrm{mM}$ of sodium chloride $\left(\mathrm{Na}^{+}\right)$. Five $\mathrm{n}$ moles of $\mathrm{Ca}^{2+}$ was added to the medium for calibration.

\section{2) Free $\mathrm{Ca}^{2+}$ content in the mitochondria}

Mitochondria (2 $\mathrm{mg}$ of protein) were incubated in the medium for $1 \mathrm{~min}$ at $24^{\circ} \mathrm{C}$ in the same manner as indicated in the $\mathrm{Ca}^{2+}$ uptake experiment. Ruthenium red $(1 \mu \mathrm{M})$ was added to inhibit energy-dependent $\mathrm{Ca}^{2+}$ uptake, and the subsequent $\mathrm{Ca}^{2+}$ release was determined following addition of the $\mathrm{Ca}^{2+}$ ionphore A23187 $\left(10^{-7} \mathrm{M}\right)$.

\section{3) Total calcium content in mitochondria}

Total calcium content in mitochondria were measured by the method of (Coll et al. 1982). Two tenths $\mathrm{ml}$ of the concentrated mitochondrial suspension containing approximately $20 \mathrm{mg}$ of protein $/ \mathrm{ml}$ was acidificed with $0.4 \mathrm{ml}$ of $14 \%(\mathrm{~W} / \mathrm{V})$ perchloric acid. The suspension was sonicated for $5 \mathrm{sec}$ and centrifuged for $30 \mathrm{sec}$ in an Eppendorf centrifuge. An aliquot of the supernatant $(0.3 \mathrm{ml})$ was diluted to $3 \mathrm{ml}$ with a mixture of $0.3 \mathrm{ml}$ of strontium chloride $(1000 \mathrm{ppm})$ and $0.3 \mathrm{ml}$ of potassium chloride $(1000 \mathrm{ppm})$ and $2.1 \mathrm{ml}$ of distilled water. The mitochondrial calcium content was determined by atomic absorption spectroscopy with Hitachi 180-80 Atomic Absorption Spectrophotometer.

\section{Results}

Figure 1 indicates the $\mathrm{Ca}^{2+}$ uptake and $\mathrm{Na}^{+}$-induced $\mathrm{Ca}^{2+}$ release of cardiac mitochondria in the control (A) and ADR treated (B) animals, as monitored by antipyrylazo III. The $\mathrm{Ca}^{2+}$ uptake velocity and release velocity are shown in Table 1 . The $\mathrm{Ca}^{2+}$ uptake and release velocities were expressed as nmoles of $\mathrm{Ca}^{2+} / \mathrm{mg}$ protien $/ \mathrm{min}$. Both the $\mathrm{Ca}^{2+}$ uptake velocity and the $\mathrm{Na}^{+}$-induced $\mathrm{Ca}^{2+}$ release velocity decreased in the ADR treated group. To determine the influence of ADR on the net amount of calcium content in mitochondria, two kinds of methods were applied to detect the mode of calcium located in the matrix: A23187 and atomic absorption determinations. The experiment shown in Fig. 2 indicates the net $\mathrm{Ca}^{2+}$ release moni- 


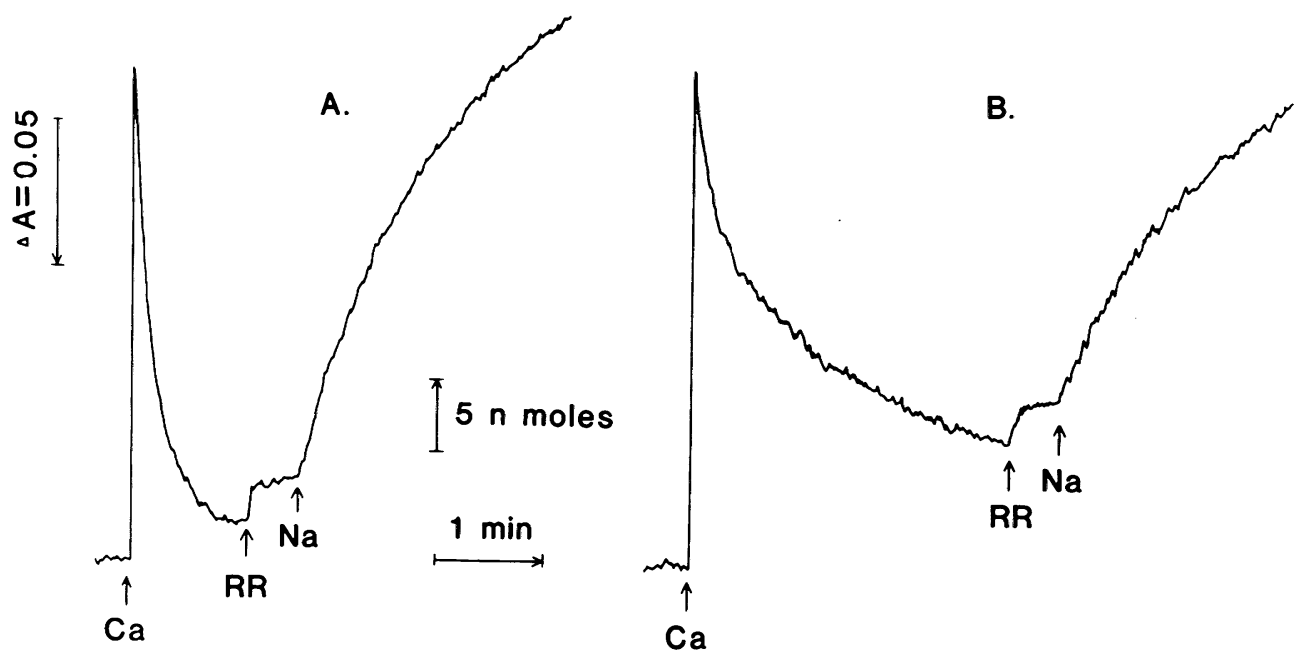

Fig. 1. The uptake and release of $\mathrm{Ca}^{2+}$ by rat heart mitochondria, as measured with the indicator antipyrylazo $\mathrm{II}$. $\mathrm{CaCl}_{2}$ was added at the point indicated to give $40 \mathrm{n}$ moles. At the completion of the uptake phase, $1 \mu \mathrm{M}$ of ruthenium red was added to inhibit further uptake and the release of $\mathrm{Ca}^{2+}$ was initiated by the addition of $10 \mathrm{mM}$ of $\mathrm{NaCl}$. A: untreated B: ADR treated.

TABLE 1

The effect of adriamycin on the $\mathrm{Ca}^{2+}$ uptake and $\mathrm{Na}^{+}$-induced $\mathrm{Ca}^{2+}$ release velocity of cardiac mitochondria

\begin{tabular}{lcc}
\hline Treatment & $\begin{array}{c}\mathrm{Ca}^{2+} \\
\text { uptake velocity }\end{array}$ & $\begin{array}{c}\mathrm{Ca}^{2+} \\
\text { release velocity }\end{array}$ \\
\hline control & $106 \pm 21$ & $11.0 \pm 1.9$ \\
ADR & $45 \pm 27^{* *}$ & $8.3 \pm 2.5^{*}$ \\
\hline
\end{tabular}

$\mathrm{n}$ moles $/ \mathrm{mg}$ protein $/ \mathrm{min}$

$* * \mathrm{p}<0.01(\mathrm{n}=6) \quad * \mathrm{p}<0.05(\mathrm{n}=7)$

TABLE 2

The effect of adriamycin on the calcium content in cardiac mitochondria

\begin{tabular}{ccc}
\hline Treatment & $\begin{array}{c}\text { free } \mathrm{Ca}^{2+} \\
(\mathrm{A} 23187)\end{array}$ & $\begin{array}{c}\text { Total calcium } \\
\text { (A. A.) }\end{array}$ \\
\hline control & $11.0 \pm 4.1$ & $11.2 \pm 2.8$ \\
ADR & $7.1 \pm 1.6^{*}$ & $7.8 \pm 1.0^{*}$ \\
\hline
\end{tabular}

$\mathrm{n}$ moles/mg protein

$* \mathrm{p}<0.05(\mathrm{n}=7)$

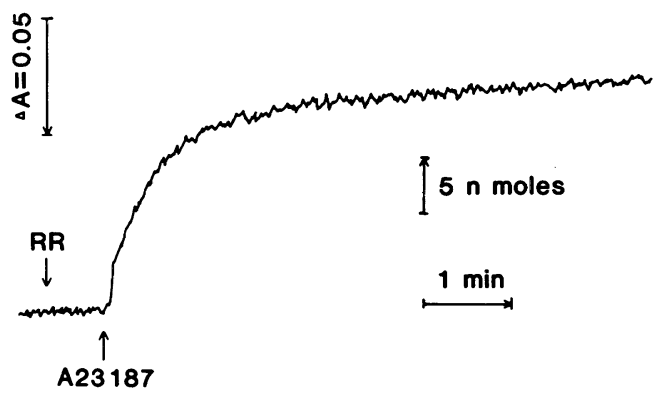

Fig. 2. Quantitation of A23187 releasable calcium from rat cardiac mitochondria. Mitochondria ( $2 \mathrm{mg}$ protein) were incubated at $24^{\circ} \mathrm{C}$ in a reaction medium, containing $80 \mu \mathrm{M}$ antipyrylazo III. The concentrations of additions were: ruthenium red (RR), $1 \mu \mathrm{M}$ : A23187, $0.1 \mu \mathrm{M}$. 
tored by antipyrylazo III after addition of $10^{-7} \mathrm{M}$ of $\mathrm{A}-23187$ in the presence of $1 \mu \mathrm{M}$ ruthenium red. Table 2 shows the $\mathrm{Ca}^{2+}$ released from cardiac mitochondria by treatment with $\mathrm{Ca}^{2+}$ ionophore A-23187. In Table 2 , the total calcium content determined by atomic absorption spectroscopy is also shown. The total calcium and free $\mathrm{Ca}^{2+}$ contents were lower in the ADR treated group, as compared with those of controls $(n=7, p<0.05)$. It was of particular interest to note that the free $\mathrm{Ca}^{2+}$ released in the presence of A-23187 was almost the same as the extractable calcium measured by atomic absorption method.

\section{Discussion}

The intracellular distribution of $\mathrm{Ca}^{2+}$, particularly the cytosolic free $\mathrm{Ca}^{2+}$ concentration, is important in regulation of cardiac cellular activities. Fiskum and Lehninger (Fiskum and Lehninger, 1982) suggested that the $\mathrm{Ca}^{2+}$ transport processes of mitochondria work together with the endoplasmic reticulum to maintain the cytosolic free $\mathrm{Ca}^{2+}$ concentration. Many biochemical and pharmacological studies have emphasized that the mitochondrial $\mathrm{Ca}^{2+}$ transport system plays a principal role in the regulation of intramitochondrial $\mathrm{Ca}^{2+}$ content (Williamson et al. 1981; McCormack and Denton, 1984; Robertson et al. 1984). Mitochondrial $\mathrm{Ca}^{2+}$ homeostasis is considered to play an important role in the regulation of myocardial cellular processes. In the present paper, the homeostasis associated with $\mathrm{Ca}^{2+}$ uptake and release from heart mitochondria was studied in ADRtreated animals. The $\mathrm{Ca}^{2+}$ uptake velocity in ADR-treated rats was found to be significatly lower than that of control. Energy of $\mathrm{Ca}^{2+}$ uptake is derived from membrane protential generated by electron transport system (Lehninger et al. 1967). Sodiuminduced $\mathrm{Ca}^{2+}$ efflux velocity was significantly lower in the ADR-treated mito- chondria. The $\mathrm{Na}^{+}$-induced $\mathrm{Ca}^{2+}$ release is known to occur as the result of electro neutral exchange to sodium (Affolter and Carafoli, 1980). The exchange velocity has been found to be influeneced by the energy state of the inner membrane and the calcium content in matrix (Goldstone et al, 1983). Both the amount of ionized $\mathrm{Ca}^{2+}$ and the total calcium content in ADRtreated animals were significantly lower than those of the controls. Also, the total calcium content was close to that of ionized calcium in both normal and ADR-treated animals. All the extractable calcium by treatment with perchloric acid located in cardiac mitochondria may be able to be released as ionized calcium.

The detailed mechanism of ADR disturbance on the $\mathrm{Ca}^{2+}$ transport of cardiac mitochondria has not been clarified yet. However, it has been suggested that the physical structure of mitochondrial membrane may play a significant role in the regulation of $\mathrm{Ca}^{2+}$ concentration and transportation (Fiskum and Lehninger, 1982). In our separate paper (Sugiyama et al. 1986), the physical states of cell membrane treated with ADR was determined by the method of ESR spin labelling technique. Results obtained with ESR showed the decreased of membrane fluidity in ADRtreated group. And also we found the lenear correlation between the membrane fluidity and the respiratory control ratio on the mitochondria (Shin, 1987). Therefore the alteration of the membrane physical properties causes deleterious effects on $\mathrm{Ca}^{2+}$ transport system of cardiac mitochondria.

Recent studies have indicated that the cytotoxic effect of ADR is related to the formation of lipid peroxide following semiquinone free radical formation (Ogura, 1982; Davies et al. 1983; Thayer, 1984). There are several papers suggesting the relationship between membrane lipid peroxidation and change of $\mathrm{Ca}^{2+}$ homeostasis (Bellomo et al. 1982; Moore et al. 1983). 
The disorders of $\mathrm{Ca}^{2+}$ homeostasis of cardiac mitochondria may have a close association with degeneration of membrane affected by lipid peroxidation. These experiments may help to provide basic information for understanding the pathogenesis of cardiotoxicity induced by ADR.

\section{References}

Affolter, H. and Carafoli, E. (1980). The $\mathrm{Ca}^{2+}$. $\mathrm{Na}^{+}$antiporter of heart mitochondria operates electroneutrally. Biochem. Biophys. Res. Commun. 95, 193-196.

Bellomo, G., Jewell, S. A., Thor, H. and OrRenius, S. (1982). Regulation of intracellular calcium compartmentation: Studies with isolated hepatocytes and $\mathrm{t}$-butylhydroperoxide. Proc. Natl. Acad. Sci. USA, 79, 6842-6846.

CoOL, K.E., Joseph, S. K., CORKEY, B.E. and Williamson, J. R. (1982). Determination of the matrix free $\mathrm{Ca}^{2+}$ concentration and kinetics of $\mathrm{Ca}^{2+}$ efflux in liver and heart mitochondria.

J. Biol. Chem. 257, 8696-8704.

Davies, K. J. A., Doroshow, J.H. and Hochstein, P. (1983). Mitochondrial NADH dehydrogenase catalyzed oxygen radical production by adriamycin, and the relative inactivity of 5 iminodaunorubicin. FEBS Lett. 153, 277-280.

Doroshow, J. H., Locker, G. Y. and Myers, C.E. (1980). Enzymatic defenses of the mouse heart against reactive oxygen metabolites. Alterations produced by doxorubicin. J. Clin. Invest. 65, $128-135$.

FARBER, J.L. (1981). The role of calcium in cell death. Life Sciences, 29, 1289-1295.

Fiskum, G. and Lehninger, A.L. (1982). Mitochondrial regulation of intracellular calcium. In Calcium and Cell Function, Vol. II, ed. W. Y. Cheung, pp. 39-80, New York: Academic Press.

Goldsone, T.P., Duddridge, R. J. and Crompton, M. (1983). The activation of $\mathrm{Na}^{+}$-dependent efflux of $\mathrm{Ca}^{2+}$ from liver mitochondria by glucagon and $\beta$-adrenergic agonists. Biochem. J. 210, 463-472.

Gornall, A. G., Bardawill, C. J. and David, M. M. (1949). Determination of serum proteins by means of the Biuret reaction. J. Biol. Chem. 177, 751-766.

Hino, Y., Yoon, S. B., Kajiyama, K., Kagiyama, A. and OGura, R. (1985). Effect of riboflavinbutyrate on cardiac glutathione reductase affected by adriamycin. J. Nutr. Sci. Vitaminol. 31, 139-145.

Jasmin, G. and Proscheк, L. (1984). Calcium and myocardial cell injury. An appraisal in the cardiomyopathic hamster. Can. J. Physiol. Pharmacol. 62, 891-898.

Mccormack, J. G. and Denton, R. M. (1984). Role of $\mathrm{Ca}^{2+}$ ions in the regulation of intramitochondrial metabolism in rat heart. Biochem. J. 62, 891-898.

Moore, G. A., Jewell, S. A., Bellomo, G. and OrRenius, S. (1983). On the relationship between $\mathrm{Ca}^{2+}$ efflux and membrane damage during $\mathrm{t}$-butylhydroperoxide metabolism by liver mitochondria. FEBS Lett. 153, 289-292.

NoHL, H. and JoRdAN, W. (1983). OH-generation by adriamycin semiquinone and $\mathrm{H}_{2} \mathrm{O}_{2}$; and explanation for the cardiotoxicity of anthracycline antibiotics. Biochem. Biophys. Res. Commun. 114, 197-205.

Nylen, E. G. and Wrogemann, K. (1983). Mitochondrial calcium content and oxidative phosphorylation in heart and skeletal muscle of dystrophic mice. Exper. Neurol. 80, 69-80.

Ogura, R. (1982). Adriamycin-induced lipid peroxidation and its prevention. In Lipid Peroxides in Biology and Medicine. ed. Yagi, K., pp. 255-269, New York: Academic Press.

Ogura, R., Hino, Y., Yoon. S. B., Kagiyama, A., IWAHASHi, H. and Hidaka, T. (1986). Assay for flavins in rat heart mitochondria by high pressure liquid chromatography. The Kurume Med. J. $33,1-6$.

Pollakis, G., Goormaghtigh, E., delmelle, M., Lion, Y. and RuYsschaert, J. M. (1984). Adriamycin and derivatives interaction with the mitochondrial membrane: $\mathrm{O}_{2}$ consumpiton and free radicals formation. Res. Commun. Chem. Pathol. Pharmacol. 44, 445-459.

Robertson, S. P., Potter, J.D. and Rouslin, W. (1982). The $\mathrm{Ca}^{2+}$ and $\mathrm{Mg}^{2+}$ dependence of $\mathrm{Ca}^{2+}$ uptake and respiratory function of porcine heart mitochondria. J. Biol. Chem. 257, 17431748.

Shin, G. (1987). Mechanism of ischemic myocardial injury-Effect of ischemia on membrane fluidity and free radical production in mitochondria- J. Kurume Med. Assoc. 50, 11621177. (in Japanese)

Sugiyama, M., Sakanashi, T., Okamoto, K., Chinami, M., Hidaka, T. and Ogura, R. (1986). Mem- 
brane fluidity of Ehrlich ascites tumor cells affected with adriamycin. Biotechnol. Appl. Biochem. 8, 217-221.

ThaYeR, W.S. (1984). Serum lipid peroxides in rats treated chronically with adriamycin. Biochem. Pharmacol. 33, 2259-2263.

Williamson, J. R., Cooper, R.H. and Hoer, J.B. (1981). Role of calcium in the hormonal regulation of liver metabolism. Biochem. Biophys. Acta 639, 243-295.

Wolkowicz, P.E., Michael, L. H., Lewis, R. M. and
Mcmillin-wood, J. (1983). Sodium-calcium exchange in dog heart mitochondria: effects of ischemia and verapamil. Am. J. Phys. H644H651.

Yoon, S. B., Kajiyama, K., Hino, Y., Sugiyama, M. and Ogura, R. (1983). Effect of adriamycin on lipid peroxide, glutahione peroxidase and respiratory responses of mitochondria from the heart, liver and kidney. Kurume Med. J. 30, 1-4. 